\title{
Ontogenetic Development of Rat Intestinal Bile Acid Transport Requires Thyroxine But Not Corticosterone
}

\author{
IONA M. MONTEIRO, ELMER S. DAVID, AND RONALDO P. FERRARIS \\ Departments of Pediatrics [I.M.M., E.S.D.] and Pharmacology and Physiology [R.P.F.], New Jersey \\ Medical School, Newark, New Jersey 07103-2714, U.S.A.
}

\begin{abstract}
ABST
Absorption of bile acids by the distal ileum is an essential
component of the enterohepatic circulation. In neonatal rats, the
appearance of the apical sodium-dependent bile acid transporter
(ASBT) at $17 \mathrm{~d}$ of age coincides with increases in serum corti-
costerone and thyroxine. We tested the hypothesis that these
hormones modulate ASBT expression during ileal development.
Taurocholate uptake into the isolated ileum of normal 20 -d-old
pups exhibited saturable $\left(\mathrm{K}_{\mathrm{m}}=0.52\right.$ mM, $\mathrm{J}_{\mathrm{max}}=0.34$ pmol
mg/min) and nonsaturable ( $\mathrm{K}_{\mathrm{diff}}=0.015$ min $\left.{ }^{-1}\right)$ components
and was two to five times greater than uptake in the proximal
intestine. Hypothyroid or euthyroid pups received daily thyrox-
ine injections starting at $6 \mathrm{~d}$ of age. At $12 \mathrm{~d}$ of age, serum
concentrations of thyroxine, ileal abundance of ASBT mRNA,
and ileal rates of taurocholate uptake were low in hypothyroid
pups that received an injection of vehicle $(\mathrm{HT}-$ ) or thyroxine
(HT+) and in euthyroid pups that received an injection of
vehicle (ET-) or thyroxine $(\mathrm{ET}+$ ). At 20 and $26 \mathrm{~d}$, ileal ASBT
mRNA abundance and taurocholate uptake rate remained low in
HT- pups but increased dramatically in ET- and ET+ pups,
paralleling the increase in serum thyroxine. Restoration of nor-
mal plasma thyroxine in HT- pups by thyroxine injections
\end{abstract}
$(\mathrm{HT}+)$ restored normal ASBT development. Sodium-glucose co-transporter activity and mRNA expression were independent of serum thyroxine levels. Corticosterone levels were significantly lower in pups that were adrenalectomized at $10 \mathrm{~d}$ of age. ASBT mRNA abundance and taurocholate uptake rate increased markedly with age but were the same in adrenalectomized, sham-operated, and nonoperated pups. Hence, endogenous thyroxine but not corticosterone regulates the developmentally timed appearance of ASBT. (Pediatr Res 55: 611-621, 2004)
ADX, adrenalectomized
Abbreviations
ASBT, apical sodium bile acid transporter
ET-, euthyroid injected with vehicle
$\mathbf{E T}+$, euthyroid injected with thyroxine
HT-, hypothyroid injected with vehicle
$\mathbf{H T}+$, hypothyroid injected with thyroxine
NOC, nonoperated controls
SGLT, sodium-dependent glucose transporter
SHAM, sham-operated

Bile acids expelled from the gallbladder into the intestinal lumen emulsify dietary lipids to aid digestion, then form micelles with the products of lipid digestion to facilitate absorption. Synthesis of bile acids by the liver is insufficient to meet physiologic needs, and bile acids are recycled in a process that involves their absorption from the intestinal lumen back into the circulation and eventual resecretion from the liver. Bile acids are absorbed passively and in modest amounts in the jejunum (1) but are absorbed actively and in greater amounts in

Received July 29, 2003; accepted November 6, 2003

Correspondence: R.P. Ferraris, Department of Pharmacology and Physiology, New Jersey Medical School, 185 S. Orange Avenue, Newark, NJ 07103-2714, U.S.A.; e-mail: ferraris@umdnj.edu

This project was supported by funds from the Foundation of UMDNJ (25-2000 to I.M.M.). Support from NSF Grants IBN-9985808 and IBN-0235011, as well as USDA Grant No. 2001-35102-09881 (to R.P.F.) are also acknowledged.

DOI: 10.1203/01.PDR.0000112126.07230.9A the distal ileum by the apical sodium-dependent transporter (ASBT) located at the brush border membrane of the enterocyte (2). It is not clear when active bile acid absorption begins during ontogenetic development of the small intestine. Sodium-dependent uptake of the bile acid taurocholate has been observed in the small intestine of an 8-mo-old child but not in that of a fetus or a neonate (3). Because reabsorption in the distal small intestine of neonates is inefficient or absent, $\sim 10$ $20 \%$ of fat intake in the formula-fed newborn is thought to be malabsorbed, even though the rate of bile acid synthesis in the neonatal liver is markedly higher than that of older age groups. In rat pups, ASBT mRNA, protein, and activity are expressed in fetal tissue, disappear completely in early neonatal life, and reappear abruptly at $17 \mathrm{~d}$ of age during early weaning (4). In contrast, the mRNA, protein, and activity of various transporters such as the rat sodium-dependent glucose transporter 
(SGLT1) and the facilitated glucose transporter GLUT2 are already significantly expressed during early gestation $(5,6)$.

The potential signals for the reappearance of bile acid transport during ontogenetic development of rats are plasma corticosterone, plasma thyroxine, and luminal bile acids. Postnatal serum corticosterone levels in rat pups are low from birth but then rise sharply at $14 \mathrm{~d}$ of age (7). This increase in serum corticosterone concentrations precedes the appearance of the intestinal brush border enzyme sucrase-isomaltase by $\sim 2-7 \mathrm{~d}$ and is known to affect enzyme development and maturation (7). Similarly, serum thyroxine concentrations also start rising during the second postnatal week in rat pups and is thought to be a possible trigger of developmental changes in the small intestine (8).

Peak serum corticosterone and thyroxine concentrations precede the abrupt reappearance of rat ASBT at $17 \mathrm{~d}$ of age and may modulate the development of ileal bile acid transport as indicated by the following studies. Uptake of taurocholate increased significantly in the ileum of 12-d-old pups that were given dexamethasone, a corticosterone analog (9). Pharmacologic doses of methylprednisolone, another corticosterone analog, accelerated the appearance of sodium-dependent taurocholate transport in ileal brush border membrane vesicles of 14-d-old rats (10). Dexamethasone-but not thyroxineinjections for $5 \mathrm{~d}$ induced ASBT mRNA expression in suckling rats $(11)$. Heubi $(12,13)$ found corticosterone to have a minor effect on postnatal development of bile salt transport. However, he has also found that 1) pharmacologic doses of exogenous thyroxine induced the precocious appearance of ileal bile acid transport in rat pups, 2) stimulation of endogenous thyroxine secretion did not precociously induce uptake, and 3) thyroidectomy did not ablate development of ileal active transport but caused a significant reduction.

Modulators of bile acid transport during development are not limited to endocrine factors. Luminal bile acids are also potential signals because feeding taurocholate to 12-d-old pups precociously induces expression of bile acid transport (14). In adult rats, the expression of ASBT is regulated at the pretranslational level by luminal cholic acids (15).

There has been no study on the effect of changes in endogenous levels of corticosterone or thyroxine on both ASBT mRNA expression and transport activity. Moreover, Heubi (12, 13) performed adrenalectomy (to remove the source of endogenous corticosterone) at $14 \mathrm{~d}$ and thyroidectomy (to remove the source of endogenous thyroxine) at $10 \mathrm{~d}$ of age. Hence, surgery was done several days after the initial surge of endogenous corticosterone (12 d of age) and of endogenous thyroxine ( $7 \mathrm{~d}$ of age) (8). It is possible that significant amounts of corticosterone or thyroxine had already been released before surgery, confounding their conclusions (13). We therefore tested the hypothesis that developmental increases in endogenous thyroxine and corticosterone levels in the early weaning rat pups are necessary for the developmental increases in both abundance of ASBT mRNA and rates of bile acid transport in the distal small intestine. Hwang and Henning (11) had a similar study but used exogenous glucocorticoid and thyroxine injections to determine their effect on mRNA abundance of ASBT. Surgical ablation of adrenal glands was done at $10 \mathrm{~d}$ of age, when corticosterone concentrations were confirmed to be low, and chemical ablation of thyroid glands in pups was initiated before birth by giving the dam propylthiouracil during late gestation.

\section{METHODS}

Animals. Pregnant (timed gestation) female Sprague Dawley rats were purchased from Charles River Laboratories (Wilmington, MA, U.S.A.) and maintained (12:12 light:dark cycle at $21^{\circ} \mathrm{C}$ ) in the Research Animal Facility with access to chow (Purina Lab Rodent Chow; Purina Mills, Richmond, IN, U.S.A.). Day of birth was designated as day 0 .

In the thyroxine study, pups were made hypothyroid by giving timed-pregnant dams $0.01 \%$ propylthiouracil as drinking water from 18 to $19 \mathrm{~d}$ of gestation until the end of the experiment, following previous work (16). Using $0.01 \%$ propylthiouracil as drinking water of late gestational dams has been previously shown to cause hypothyroidism in rat pups (17). A second group of dams had age-matched euthyroid pups that served as controls. One half of pups from each group received daily injections of thyroxine $(0.05 \mu \mathrm{g} / \mathrm{g}$ body weight, i.p.; Sigma Chemical Co., St. Louis, MO, U.S.A.) starting on day 6 of life, and the other half received injection of vehicle (0.3 mM NaOH). Hence, there were four groups: hypothyroid injected with vehicle (HT-), hypothyroid injected with thyroxine $(\mathrm{HT}+)$, euthyroid injected with vehicle $(\mathrm{ET}-)$, and euthyroid injected with thyroxine $(\mathrm{ET}+)$. All pups stayed with the dam until killed, and were allowed to wean (have access to chow) at the appropriate time. The pups were then killed at 12, 20 , and $26 \mathrm{~d}$ of age. In the corticosterone study, pups were randomly selected at $10 \mathrm{~d}$ of age for adrenalectomy, sham operation, or use as nonoperated controls (NOC; see "Adrenalectomy" below for details). In both studies, pups were anesthetized and weighed, then blood was collected via intracardiac puncture. Blood was centrifuged $\left(8000 \times g, 4^{\circ} \mathrm{C}\right)$ for $10 \mathrm{~min}$ in an Eppendorf microcentrifuge 5402 (Brinkmann Instruments, Grand Island, NY, U.S.A.), and the serum was stored at $-20^{\circ} \mathrm{C}$ for thyroxine (study 1) and corticosterone (study 2) RIA. The body cavity was opened, and small intestine was immediately perfused with ice-cold $\left(2^{\circ} \mathrm{C}\right)$ mammalian Ringer (composition in $\mathrm{mM}: 128 \mathrm{NaCl}, 4.7 \mathrm{KCl}$, $2.5 \mathrm{CaCl}_{2} \cdot 2 \mathrm{H}_{2} \mathrm{O}, 1.2 \mathrm{MgSO}_{4}, 19 \mathrm{NaHCO}_{3}$, and $1.2 \mathrm{KH}_{2} \mathrm{CO}_{3}$ ). The intestine was removed, washed in ice-cold Ringer, blotted gently on moist filter paper, suspended for length measurements, then weighed in an analytical balance. The intestine was then gently everted on a 1-mm steel rod, and 1-cm segments were removed for determinations of taurocholate and glucose uptake rates (see below). The remainder of the distal intestine was frozen in liquid nitrogen for Northern blot analysis at a later date. Experimental procedures were approved by the Institutional Animal Care and Use Committee of the University of Medicine and Dentistry of New Jersey.

Adrenalectomy. Under anesthesia with ketamine cocktail (0.1 mL/30 g body weight; composition in $\mathrm{mg} / 10 \mathrm{~mL}: 10$ ketamine; 2 xylazine, and 1 acepromazine), bilateral adrenalectomies were performed in 10-d-old pups using the procedure described previously (18). After surgery and recovery from anesthesia, the pups rejoined the dam until the time that they 
were killed. In the sham-operated (SHAM) littermates, a similar procedure was followed except that the adrenal glands were only gently grasped with the forceps but not removed. From the day after surgery ( $11 \mathrm{~d}$ of age), the adrenalectomized (ADX) pups received daily s.c. injections of aldosterone $(0.05$ $\mu \mathrm{g} / \mathrm{g}$ body weight; Sigma Chemical Co.) to prevent salt and water wasting secondary to the lack of mineralocorticoids (19). All pups that recovered from surgery survived until the end of the experiment. The pups were then killed at 15, 20, and $26 \mathrm{~d}$ of age. The success rate of the adrenalectomy was $>80 \%$ as pups with $>60 \mathrm{ng} / \mathrm{mL}$ corticosterone were rejected.

Uptake measurements. Before the thyroxine or corticosterone studies, the kinetic parameters of taurocholate uptake into everted intestinal sleeves were initially estimated using 20-dold normal pups. Bile acid and glucose uptakes in the intestinal mucosa of rats used in subsequent thyroxine and corticosterone studies were then measured using the everted sleeve technique described previously $(16,18)$.

Rats were anesthetized with a ketamine cocktail $(0.2 \mathrm{~mL} / 30$ g body weight). (Because these were nonsurvival surgeries, a higher concentration of anesthesia was used than during adrenalectomy.) After the wet weight and length of the dissected small intestine were determined, the proximal $(2-6 \mathrm{~cm}$ distal to the ligament of Treitz, total length $4 \mathrm{~cm})$ and distal $(2-6 \mathrm{~cm}$ proximal to the cecum, total length $4 \mathrm{~cm}$ ) small intestines were each everted on metallic rods. The 1-cm-long everted sleeves were removed from each segment, mounted on grooved metallic rods, then preincubated for $5 \mathrm{~min}$ in oxygenated mammalian Ringers solution (bubbled with $95 \% \mathrm{O}_{2} / 5 \% \mathrm{CO}_{2}$ at $37^{\circ} \mathrm{C}$ ). Sleeves were then incubated in solutions that contained the test tracers $\left[{ }^{3} \mathrm{H}\right]$ taurocholate or $\left[{ }^{14} \mathrm{C}\right] \mathrm{D}$-glucose for bile acid and glucose uptake measurements, respectively. $\left[{ }^{14} \mathrm{C}\right]$ Polyethylene glycol was added to the taurocholate incubation solution to correct for adherent fluid, then total (active plus passive) taurocholate uptake was measured. $\left[{ }^{3} \mathrm{H}\right] \mathrm{L}$-glucose was added to the glucose incubation solution to correct simultaneously for adherent fluid and for passive uptake of D-glucose, thereby measuring only carrier-mediated, active uptake of glucose. The incubation time was $2 \mathrm{~min}$ for taurocholate and $1 \mathrm{~min}$ for glucose. The sleeve for glucose uptake was then rinsed for $20 \mathrm{~s}$ in ice-cold Ringers solution to wash off radioactive label in the adherent fluid. In the thyroxine and corticosterone studies, uptake rates for taurocholate and glucose were determined at 6and $50-\mathrm{mM}$ concentrations, respectively. These concentrations lead to uptakes that are near the $V_{\max }$ for each substrate, and the $V_{\max }$ determinations are not affected by errors caused by unstirred layers (20). For taurocholate, $6 \mathrm{mM}$ is also close to the estimated taurocholate concentrations in the intestinal lumen (21). The range of human luminal bile acid concentrations is $0.1 \mathrm{mM}$ (cholic acid) to $12 \mathrm{mM}$ (glycocholic acid) (22). All radioactive isotopes were purchased from DuPont NEN (Boston, MA, U.S.A.).

In determinations of kinetic parameters of taurocholate uptake in everted intestinal sleeves, $0.1,0.4,1,3,10$, and $20 \mathrm{mM}$ taurocholate concentrations were used. This range of taurocholate concentrations has previously been used successfully to determine kinetics of taurocholate transport in vivo (23).

\section{RIA}

Serum thyroxine and corticosterone levels were determined using the $\mathrm{T}_{4} \mathrm{MaB}$ and the ${ }^{125} \mathrm{I}$ RIA kits, respectively (ICN Biomedicals, Costa Mesa, CA, U.S.A.). Radioactivity was counted in a gamma counter (Canberra Systems), and the concentrations of thyroxine and corticosterone were determined from standard curves generated with each assay, as described previously $(16,18)$.

\section{RNA ISOLATION AND NORTHERN BLOT ANALYSIS}

The single-step isolation technique was used to extract total RNA (24) as modified by (16). Total RNA (40 $\mu \mathrm{g}$ ) was loaded on a denaturing $1 \%$ agarose/formaldehyde gel $(65 \mathrm{~V} / \mathrm{cm})$. The RNA was transferred overnight to a nylon membrane (ICN Biomedicals) by capillary blotting. The RNA was then fixed onto the membrane by baking in an oven under vacuum at $80^{\circ} \mathrm{C}$ for $2 \mathrm{~h}$. The RNA blot was probed with rat ASBT cDNA (provided by Dr. B. Shneider) using the Random Primed DNA Labeling Kit (Boehringer Mannheim, Indianapolis, IN, U.S.A.). ${ }^{32}$ P-labeled probe was added to the membrane, and the membrane was incubated in the hybridization oven at $42^{\circ} \mathrm{C}$ overnight. The membrane was washed, rinsed, air-dried, and then exposed to x-ray film. Several x-ray films were used for each membrane, and all films were checked for saturation. The membrane was stripped then reprobed with rat $18 \mathrm{~S}$ cDNA as the loading and transfer control. Quantification was performed by densitometry (IS-1000 Digital Imaging Systems; Alpha Innotech Corp., San Leandro, CA, U.S.A.). The density of ASBT mRNA was initially normalized to that of the loading control 18S rRNA, and then the resulting ratio was expressed as relative percentage of the ratio in the HT + (thyroxine study, $12 \mathrm{~d}$ old) or SHAM (corticosterone study, $15 \mathrm{~d}$ old) group (designated as 100\%).

\section{STATISTICAL ANALYSIS}

A two-way ANOVA was used to analyze the simultaneous effects of hormonal status and age of pups on body weights, intestinal weights, intestinal lengths, serum thyroxine (or corticosterone) levels, uptake of taurocholate or glucose, and relative ASBT mRNA levels. A two-way ANOVA was also used to analyze the simultaneous effects of thyroxine status (or adrenalectomy) and intestinal position on the uptake of taurocholate or glucose in the small intestine within an age group. A $p \leq 0.05$ was considered statistically significant. When the effects were significant, a one-way ANOVA was used to identify specific significant differences within an age group. Statistical analysis was done using the StatView Program (Abacus Concepts, Berkeley, CA, U.S.A.). Estimates of $\mathrm{K}_{\mathrm{m}}$ and $V_{\max }$ used the Enzfitter Program (BioSoft, Ferguson, MO, U.S.A.).

\section{RESULTS}

\section{Kinetic parameters of bile acid transport}

Effect of duration of incubation and intestinal region on bile acid absorption. We determined the time course (0.5-20 $\mathrm{min})$ of taurocholate $(6 \mathrm{mM})$ uptake using the ileum from late 
weaning $(22 \mathrm{~d})$ rat pups. There was a rapid linear increase in taurocholate uptake until 2 min followed by a much slower increase from 2 to $20 \mathrm{~min}$. Next we studied the effect of intestinal region on taurocholate uptake, using $2 \mathrm{~min}$ as incubation time, following the criteria of Karasov and Diamond (25). As would be expected, uptake was nearly $60 \%$ higher in the distal compared with the proximal small intestine (results not shown, but similar results were observed in subsequent experiments of this study).

Kinetics of bile acid transport into rat distal small intestine. Because all previous studies and our preliminary work indicated that bile acids are not actively transported and ASBT mRNA are not present in the jejunum (26-28), we estimated only the kinetics of bile acid into isolated sleeves of rat distal small intestine. The apparent $\mathrm{K}_{\mathrm{m}}$ of taurocholate uptake into everted sleeves of distal intestine is $0.52 \pm 0.17 \mathrm{mM}$, and the $\mathrm{J}_{\max }$ is $0.34 \pm 0.06 \mathrm{pmol} \mathrm{mg} / \mathrm{min}$. The apparent $\mathrm{K}_{\mathrm{d}}$ for the noncarrier-mediated pathway is $0.015 \pm 0.002 \mathrm{~min}^{-1}$.

\section{Thyroxine study}

Morphometric parameters. The body weights of the ET + , ET - , HT +, and HT - rat pups were similar at $12 \mathrm{~d}$ of age ( $p=0.4$, by one-way ANOVA; Fig. $1 A$ ). However, body weights of the HT- pups were significantly lower than those of the other three groups at 20 and $26 \mathrm{~d}$ of age $(p<0.001$ and $p<$ 0.0001 , respectively). The wet intestinal weight ( $p=0.003$ and
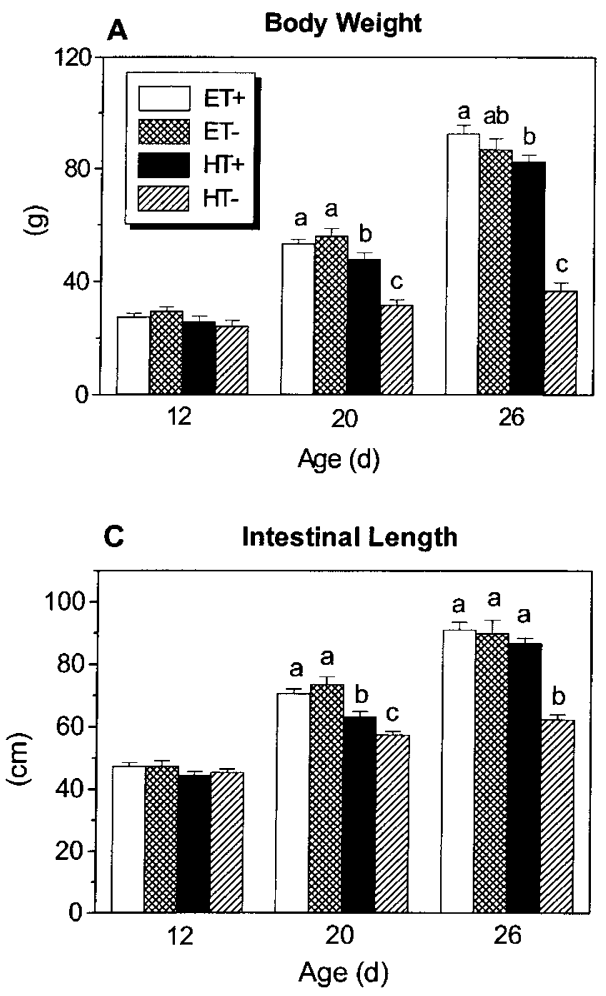

$<0.0001$; Fig. $1 B)$ and intestinal length $(p<0.0005$ and $p<$ 0.0001 ; Fig. 1C) were also lower in the HT- pups at age 20 and $26 \mathrm{~d}$. Because age-related increases in intestinal weight were greater than those in intestinal length, weight (or amount of tissue) per centimeter of intestine also increased with age (not shown).

Serum thyroxine levels. By two-way ANOVA, there is a significant effect of thyroxine treatment $(p<0.0001)$ but not of age $(p=0.10)$ on thyroxine levels in 12-, 20-, and 26-d-old pups (Fig. 1D). The thyroxine levels in the HT- pups were significantly lower than those in the ET+, ET-, and HT+ pups at 12,20, and $26 \mathrm{~d}$ of age ( $p<0.0001$ in each age group, by one-way ANOVA). As would be expected, the serum thyroxine level in normal euthyroid pups was low on day 6 and did not increase ( $p=0.7$, by one-way ANOVA) in the HT - pups at age 12,20 , and $26 \mathrm{~d}$. In contrast, thyroxine levels in ET+, ET -, and HT + pups increased markedly when compared with 6-d-old normal pups $(p<0.001)$. Levels of thyroxine in ET - and HT - pups in this study are similar to those in euthyroid and hypothyroid pups from our previous work (16). Thyroxine levels in 6-d-old pups are similar to those in same-age pups described previously [see review by Henning (8)].

Bile acid uptakes. Taurocholate uptake per milligram in the proximal small intestine varied with age $(p=0.007$; Fig. $2 A)$ but not with thyroxine treatment $(p=0.6$, by two-way ANOVA). The overall mean (across treatment groups) uptake per milligram was $0.089 \pm 0.011,0.100 \pm 0.020$, and $0.036 \pm$
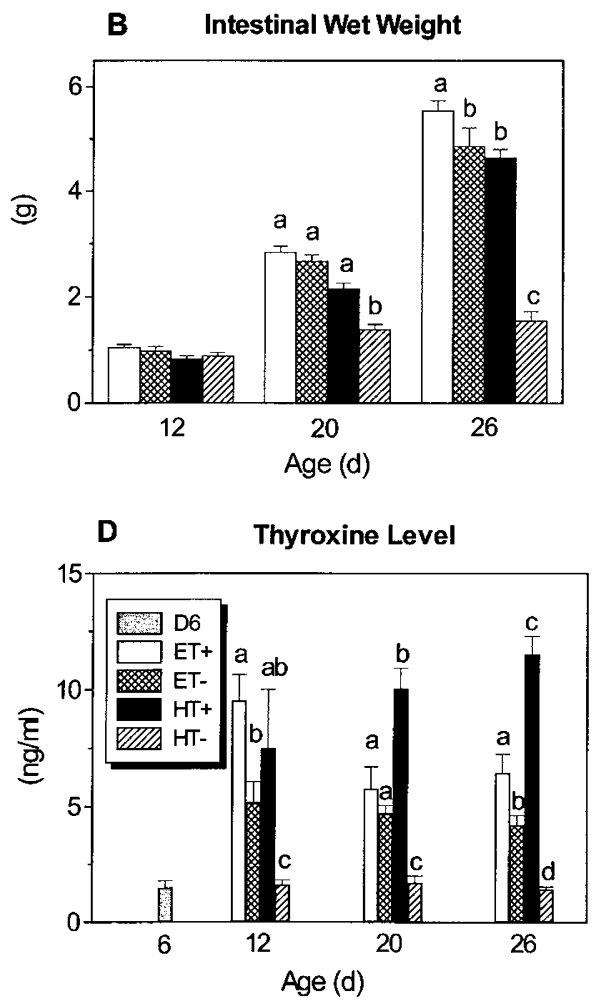

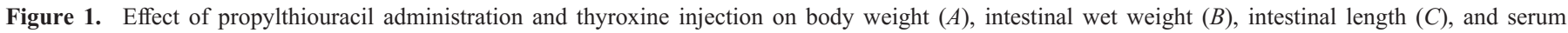

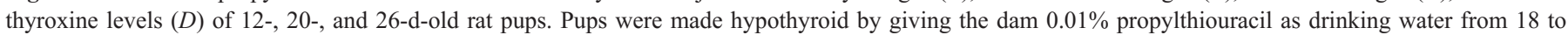

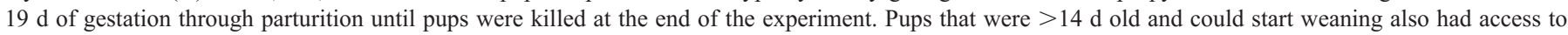

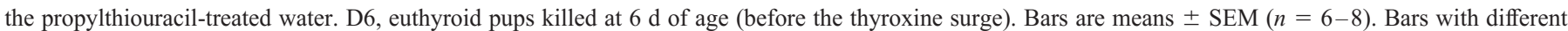

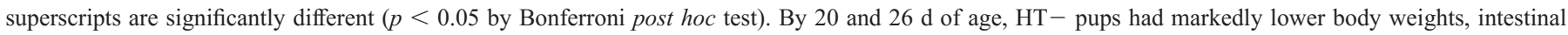
wet weights, intestinal lengths, and serum thyroxine levels than those of other pups. 
A Taurocholate Uptake, Proximal Intestine

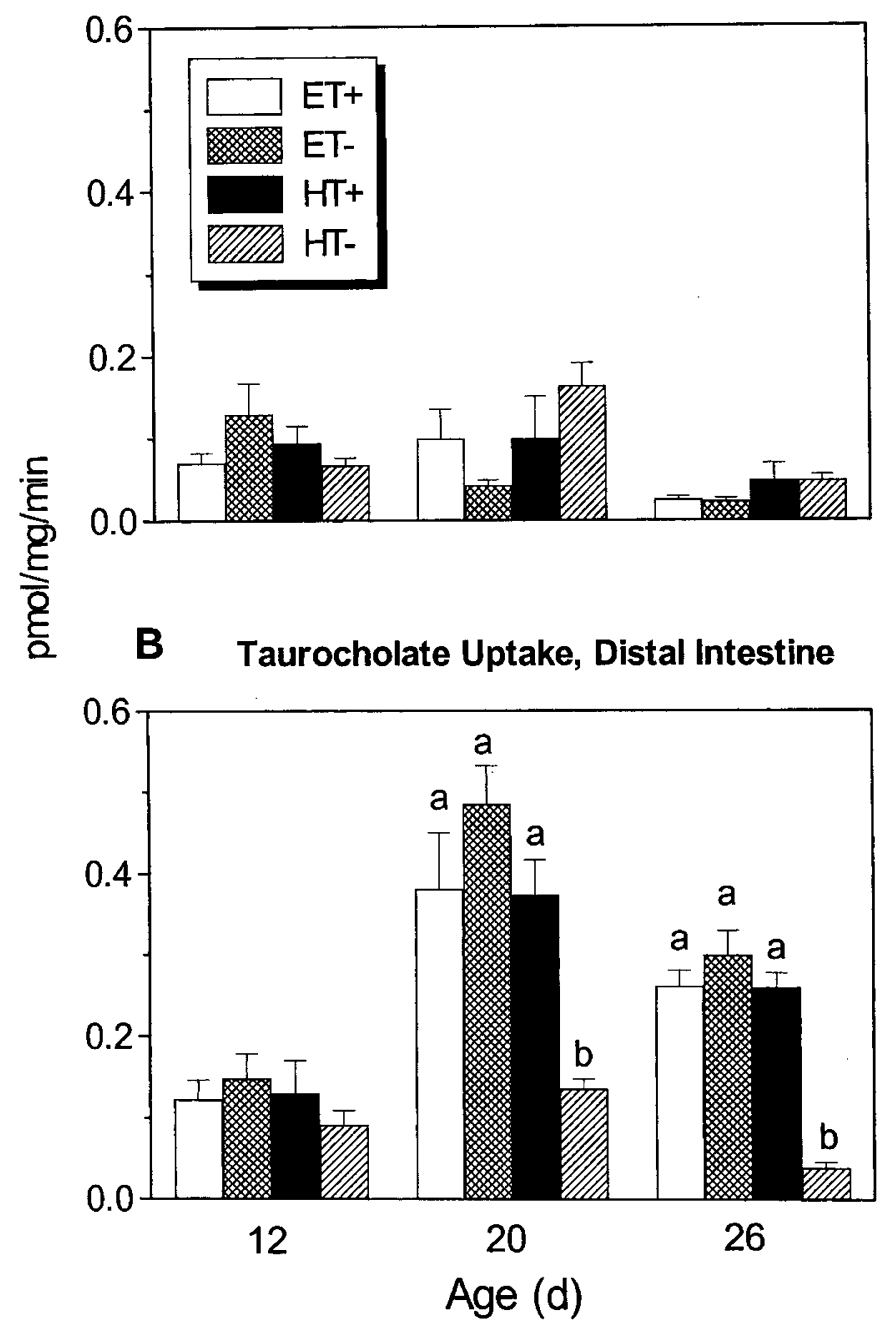

Figure 2. Taurocholate uptake in the proximal $(A)$ and distal $(B)$ small intestine of ET,$+ \mathrm{ET}-, \mathrm{HT}+$, and $\mathrm{HT}-$ pups. Bars are means $\pm \mathrm{SEM}(n=$ $6-8)$; those with different superscripts are significantly different $(p<0.05)$. Uptake in the proximal region was low and decreased modestly with age and was unaffected by thyroxine status. Uptake in the distal region increased markedly with age except in HT- pups.

$0.008 \mathrm{pmol} \cdot \mathrm{mg}^{-1} \cdot \mathrm{min}^{-1}$ at 12,20 , and $26 \mathrm{~d}$ of age, respectively, and therefore decreased with age $(p<0.01)$. In the distal small intestine, bile acid uptake per milligram increased significantly with the age of the pups $(p<0.0001$; Fig. $2 B)$ and also varied among treatment groups $(p<0.0001$, by two-way ANOVA). The overall mean (across all treatment groups) bile acid uptake per milligram increased two to three times with age and was $0.123 \pm 0.015,0.368 \pm 0.03$, and $0.244 \pm 0.014 \mathrm{pmol} \cdot \mathrm{mg}^{-1} \cdot \mathrm{min}^{-1}$ at ages 12,20 , and $26 \mathrm{~d}$, respectively. Bile acid uptake per milligram in the distal intestine of HT - pups remained low at all ages. The mean bile acid uptake per milligram in the distal small intestine in the HTpups was significantly lower than those in the $\mathrm{ET}+, \mathrm{ET}-$, and HT + pups at 20 and $26 \mathrm{~d}$ of age $(p<0.004$ and 0.0001 , respectively). Taurocholate uptake was greater in the distal than in the proximal small intestine $(p<0.0001)$ in 20 - and 26but not 12-d-old pups.
Glucose uptakes. In the proximal small intestine, glucose uptake per milligram did not vary with age ( $p=0.57$; Fig. $3 A$ ) and treatment ( $p=0.48$, by two-way ANOVA). The overall mean uptake per milligram was $6.00 \pm 0.41,5.85 \pm 0.56$, and $5.30 \pm 0.46 \mathrm{nmol} \cdot \mathrm{mg}^{-1} \cdot \mathrm{min}^{-1}$ at 12,20 , and $26 \mathrm{~d}$ of age, respectively. In the distal small intestine, uptake per milligram decreased modestly with age ( $p=0.03$; Fig. $3 B$ ) but not with treatment $(p=0.58)$. This age-related decrease in glucose uptake suggests that the highly significant age-related increase in taurocholate uptake per milligram by the distal small intestine was specific. The overall mean glucose uptake per milligram was $3.02 \pm 0.22,3.60 \pm 0.44$, and $2.17 \pm 0.19 \mathrm{nmol} \cdot$ $\mathrm{mg}^{-1} \cdot \min ^{-1}$ at 12,20 , and $26 \mathrm{~d}$ of age, respectively. Glucose uptake in each age group was greater in the proximal than in the distal intestine $(p<0.0001)$ but was independent of thyroxine status $(p>0.10)$.

ASBT mRNA expression. The density of the ASBT mRNA in the distal small intestine varied significantly among the four treatment groups ( $p=0.0012$; Fig. $4 A$ and $B$ ) and also

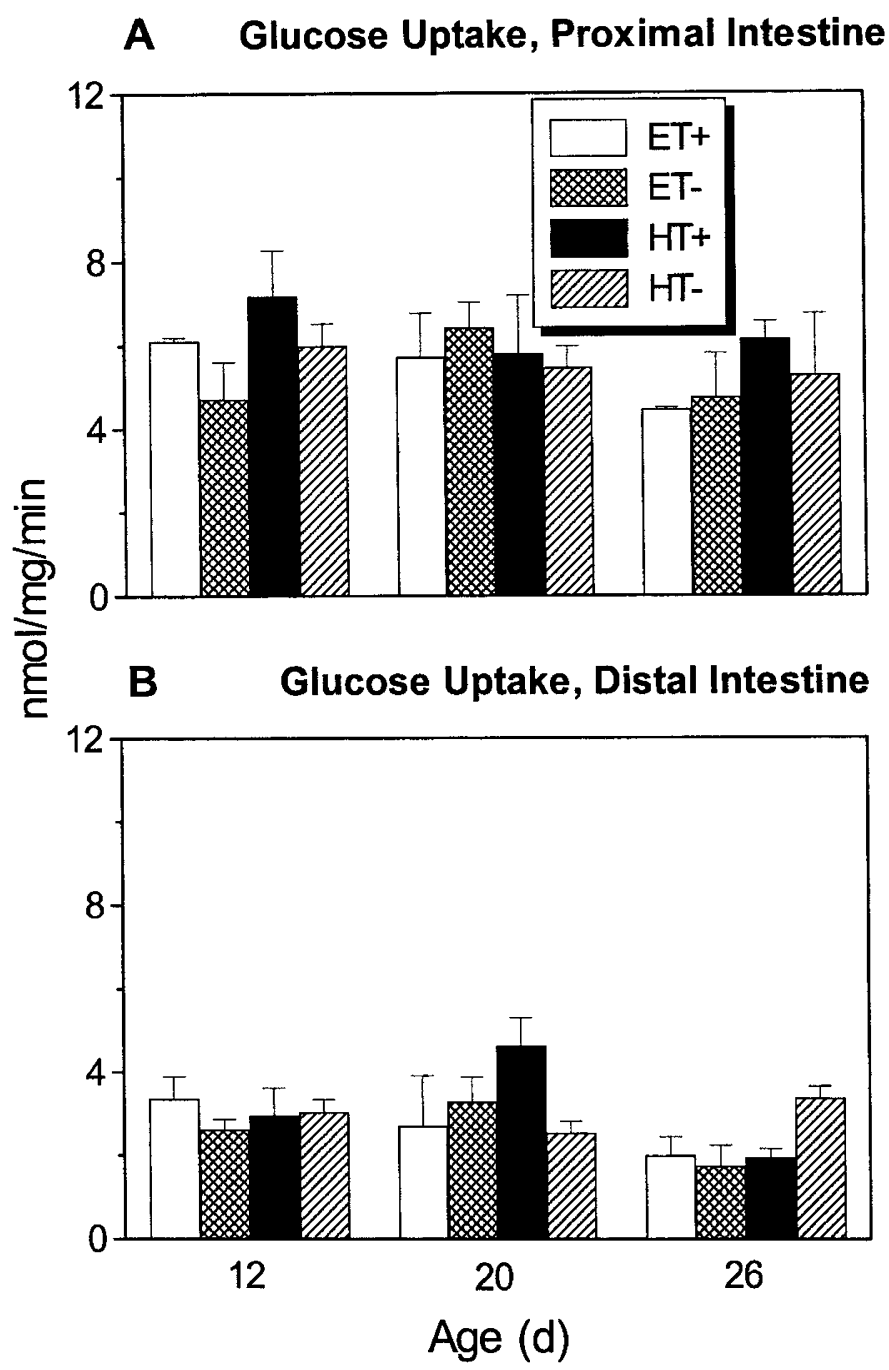

Figure 3. Glucose uptake in the proximal $(A)$ and distal $(B)$ small intestine of $\mathrm{ET}+, \mathrm{ET}-, \mathrm{HT}+$, and HT - pups. Bars are means $\pm \mathrm{SEM}(n=6-8)$. Uptake was greater in the proximal than in the distal small intestine. Uptake in the distal intestine decreased slightly with age in all pups. Uptake in both regions was independent of serum thyroxine concentrations. 
increased significantly with age $(p<0.0001$, by two-way ANOVA). The mean relative ASBT density across all age groups was three to five times lower in the HT - pups $(p=$ 0.014 ), as follows: $472 \pm 114,409 \pm 99,328 \pm 73$, and $86 \pm$ 26 in the $\mathrm{ET}+$, ET - , HT + , and HT- pups, respectively. Across treatment groups, the mean relative density of the ASBT mRNA was $86 \pm 9$ in 12-d-old pups, then quadrupled at $375 \pm 83$ in 20-d-old pups, and increased further to $508 \pm$ 85 in 26-d-old pups. The density of SGLT1 mRNA did not vary with age $(p=0.06$, by two-way ANOVA) or with treatment ( $p=0.58$; Fig. $4 A$ and $C$ ). Across treatment groups,
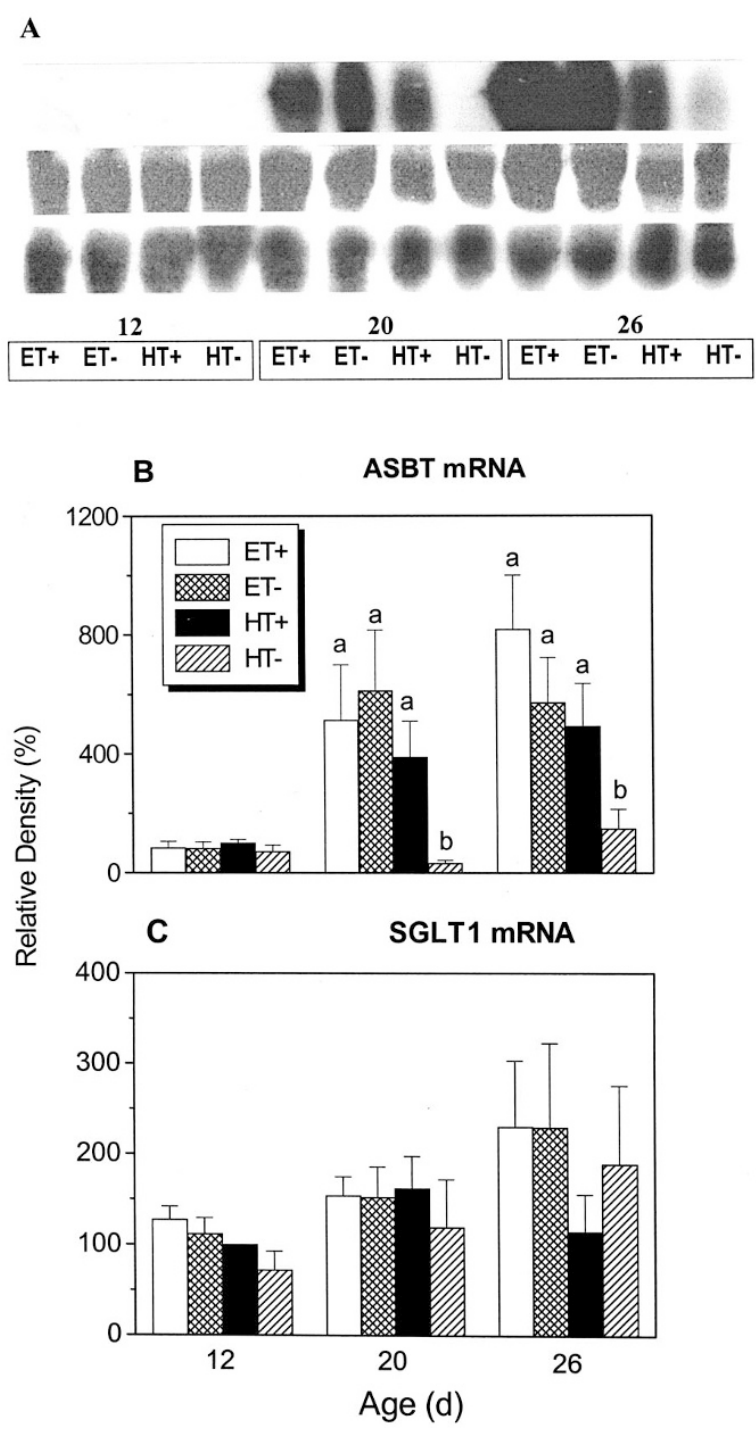

Figure 4. (A) A representative Northern blot analysis of ASBT (top row) and SGLT1 (middle) mRNA as well as 18S rRNA (bottom) in the distal small intestine of ET-, ET +, HT-, and HT + pups at 12, 20, and $26 \mathrm{~d}$ of age. (B) Mean relative abundance of ASBT mRNA. 18S rRNA was used as loading and transfer control. Abundance was initially normalized to $18 \mathrm{~S}$ rRNA, and the normalized ASBT mRNA abundance was expressed relative to that in the distal small intestine of 12-d-old HT + pups (designated arbitrarily as $100 \%)$. Bars are means $\pm \operatorname{SEM}(n=4)$. Except in HT - pups, abundance of ASBT mRNA increased markedly with age. (C) Mean relative abundance of SGLT1 mRNA. Controls and normalization procedure are the same as in $B$. Bars are means $\pm \operatorname{SEM}(n=4)$. Abundance of SGLT1 mRNA was independent of age and of thyroxine status. the mean relative density of the SGLT1 mRNA was $1.03 \pm$ $0.09,1.47 \pm 0.17$, and $1.91 \pm 0.35$ at 12,20 , and $26 \mathrm{~d}$ of age, respectively.

\section{Corticosterone study}

Morphometric parameters. The body weights of the ADX rat pups were not significantly different from those of the SHAM and NOC littermates at age $15 \mathrm{~d}(p=0.61$; Fig. $5 A)$. However, body weights of the ADX pups were significantly lower than those of SHAM and NOC pups when killed at 20 and $26 \mathrm{~d}$ of age $(p=0.037$ and 0.01 , respectively). The wet intestinal weight $(p=0.02$; Fig. $5 B)$ and intestinal length $(p=$ 0.004; Fig. 5C) were also lower in the ADX pups at age $26 \mathrm{~d}$.

Serum corticosterone levels. As would be expected, the serum corticosterone level was low on in NOC 10-d-old pups and did not increase ( $p=0.8$, by one-way ANOVA) in the ADX pups at age 15,20 , and $26 \mathrm{~d}$ (Fig. $5 D$ ). This suggests that adrenalectomy totally prevented the corticosterone surge. Overall, the corticosterone levels in the ADX pups were significantly lower than those in the SHAM and NOC pups $(p=$ 0.0007 for effect of surgery, $p=0.02$ for effect of age, by two-way ANOVA). When compared with the corticosterone levels of 10-d-old NOC pups and of ADX pups, those of the NOC and SHAM pups were markedly greater by $20(p=0.02)$ and $26(p=0.03) \mathrm{d}$ of age. Serum corticosterone levels in 15and 20-d-old ADX, SHAM, and NOC pups are similar to those in 20-d-old ADX, SHAM, and NOC pups, respectively, from a previous study (18).

Bile acid uptakes. Taurocholate uptake per milligram in the proximal small intestine did not vary with age $(p=0.4$; Fig. $6 A$ ) or with adrenalectomy ( $p=0.09$, by two-way ANOVA). The overall mean (across surgical groups) uptake per milligram at each age group was $0.068 \pm 0.005,0.062 \pm 0.006$, and $0.060 \pm 0.006 \mathrm{pmol} \cdot \mathrm{mg}^{-1} \cdot \mathrm{min}^{-1}$ at 15,20 , and $26 \mathrm{~d}$ of age, respectively. In the distal small intestine, bile acid uptake per milligram increased significantly with the age of the pups $(p<$ 0.0001 ; Fig. $6 B$ ) but did not change with adrenalectomy $(p=$ 0.44 , by two-way ANOVA). The overall mean (across surgical groups) bile acid uptake per milligram increased by almost 3 -fold with age: $0.105 \pm 0.048,0.337 \pm 0.039$, and $0.404 \pm$ $0.035 \mathrm{pmol} \cdot \mathrm{mg}^{-1} \cdot \mathrm{min}^{-1}$ at ages 15,20 , and $26 \mathrm{~d}$, respectively. Bile acid uptakes at 20 and $26 \mathrm{~d}$ of age were greater $(p$ $<0.0001)$ in the distal than in the proximal small intestine.

Glucose uptakes. In the proximal small intestine, glucose uptake per milligram did not vary with age ( $p=0.6$; Fig. $7 A)$ and adrenalectomy ( $p=0.6$, by two-way ANOVA). The overall mean uptake per milligram was $7.45 \pm 0.44,6.54 \pm$ 0.92 , and $7.37 \pm 0.81 \mathrm{nmol} \cdot \mathrm{mg}^{-1} \cdot \mathrm{min}^{-1}$ at 15,20 , and $26 \mathrm{~d}$ of age, respectively. These uptake measurements are similar to those of recent previous experiments in same-age pups, indicating that glucose transporter activity in these intestines was normal $(16,29)$.

Like the thyroxine experiment, uptake per milligram in the distal small intestine decreased modestly with age (borderline $p=0.05$; Fig. $7 B)$ but not with adrenalectomy $(p=0.43)$. The overall mean uptake per milligram was $4.07 \pm 0.35,3.45 \pm$ 0.77 , and $2.27 \pm 0.27 \mathrm{nmol} \cdot \mathrm{mg}^{-1} \cdot \mathrm{min}^{-1}$ at 15,20 , and $26 \mathrm{~d}$ 

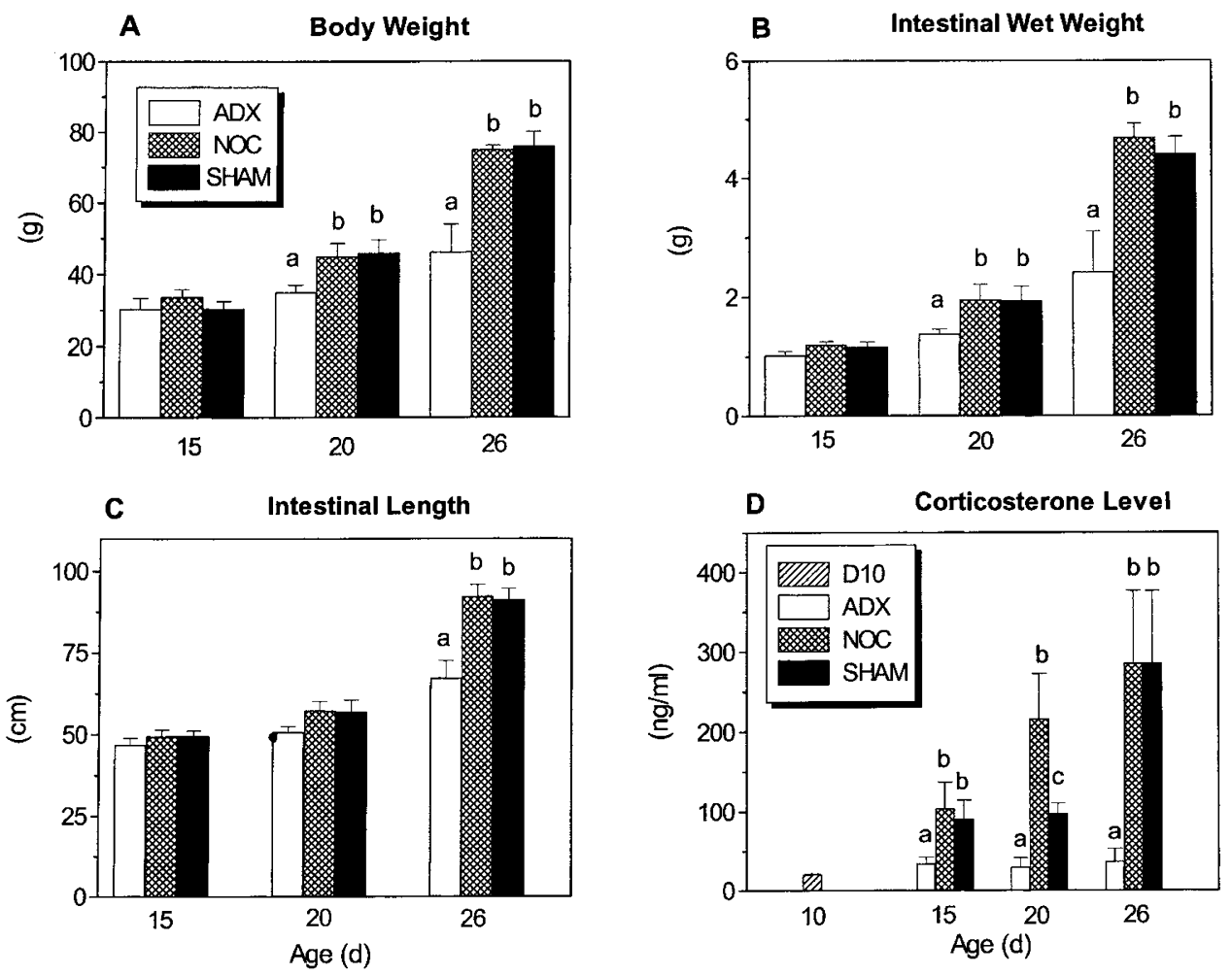

Figure 5. Body weight $(A)$, intestinal wet weight $(B)$, intestinal length $(C)$, and serum corticosterone concentrations $(D)$ of pups that were adrenalectomized (ADX), were sham-operated (SHAM), or remained with the dams and therefore were nonoperated controls (NOC). D10, nonoperated pups killed at $10 \mathrm{~d}$ of age, before the corticosterone surge. Bars are means \pm SEM $(n=6-8)$. Adrenalectomy generally decreased body weight, intestinal weight, and intestinal length in 20- and 26-d-old pups. Serum corticosterone concentrations were low in 10-d-old pups and remained low in ADX pups.

of age, respectively. Unlike taurocholate uptake, glucose uptake was greater in the proximal than in the distal small intestine ( $p<0.0001$ in each age group).

ASBT $\boldsymbol{m R N A}$ expression. The density of the ASBT mRNA in the distal small intestine did not vary significantly among the three treatment groups ( $p=0.96$; Fig. 8) but increased significantly with age ( $p=0.0019$, by two-way ANOVA). Within treatment groups, the mean relative density of the ASBT mRNA was $146 \pm 41$ on day 15 , then doubled at $330 \pm 100$ on day 20 , and quadrupled at $780 \pm 140$ on day 26 . The age-related increases in ASBT mRNA expression in this study are similar in magnitude to the age-related increases in ASBT mRNA expression of normal rats in the thyroxine study.

\section{DISCUSSION}

Normal ASBT development requires thyroxine. Our main finding is that thyroxine is required for the normal ontogenetic appearance of ASBT mRNA and function in the distal small intestine of rat pups, for the following reasons. First, the endogenous surge in serum thyroxine in 12-d-old euthyroid pups preceded a dramatic increase in ASBT mRNA abundance and in bile acid uptake rates in the distal small intestine of 20-d-old pups. Inhibition of the endogenous surge prevented the increases in ASBT mRNA abundance and bile acid uptake rates. Second, replacement of endogenous thyroxine by injections of exogenous thyroxine into hypothyroid pups led not only to expected increases in serum thyroxine but also to marked increases in ASBT mRNA abundance and in bile acid uptake rates. Third, the mRNA abundance and activity of an unrelated transporter, SGLT1, did not vary with thyroxine status. Moreover, glucose uptake rates were similar to those of previous work from this laboratory $(16,18,30)$. This indicates not only that the intestinal mucosae of all pups were capable of normal glucose uptakes but also that the effects of thyroxine on ASBT are specific and not nonspecific secondary to the changes in hormonal status.

Our main conclusion differs from that of Heubi (13), who found that thyroidectomy in rat pups at $10 \mathrm{~d}$ of age did not prevent development of active ileal bile acid uptake at $21 \mathrm{~d}$ of age. Different conclusions may have arisen because thyroidectomy in Heubi's study might not have completely eliminated production of thyroxine or that thyroxine was already present before thyroidectomy at $10 \mathrm{~d}$ of age. Compared with that in 5-d-old pups, serum thyroxine has already increased significantly in 7-d-old pups (31).

ASBT mRNA abundance has also been shown to increase when thyroxine was given simultaneously with dexamethasone to suckling pups (11), indicating that exogenous thyroxine and corticosteroids can precociously enhance ASBT expression. This study supplemented endogenous with exogenous thyroxine and differs from our work that determined the effect of preventing the endogenous thyroxine surge on ASBT expression. Because we did not measure corticosterone levels in our thyroxine study, we cannot eliminate the possibility that high plasma thyroxine levels were linked with high plasma corticosterone levels and that both thyroxine and corticosterone in- 


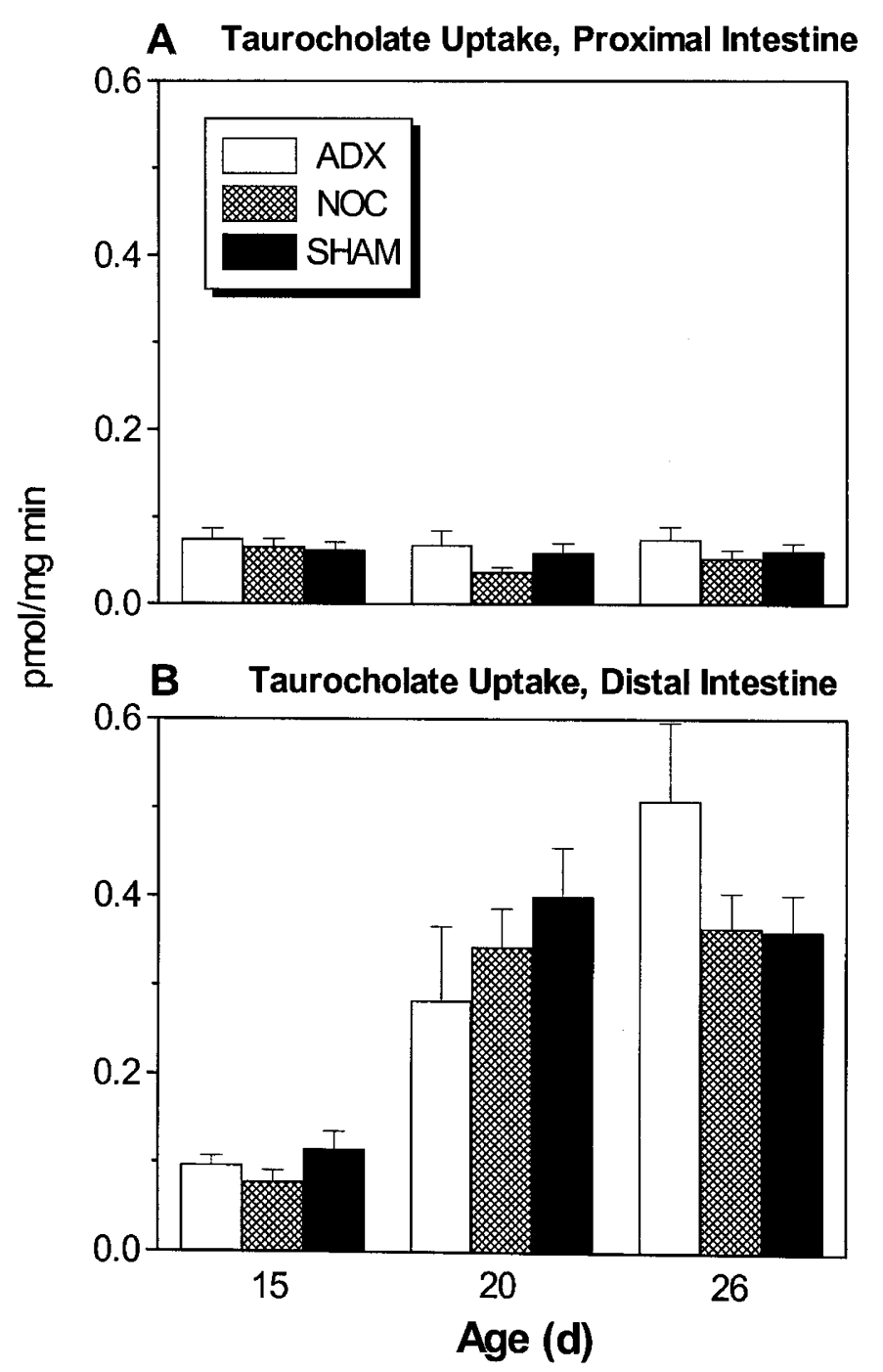

Figure 6. Taurocholate uptake in the proximal $(A)$ and distal $(B)$ small intestine of ADX, SHAM, or NOC pups. Bars are means \pm SEM $(n=6-8)$. In the proximal small intestine, taurocholate uptake was low and was independent of age and treatment. In the distal small intestine, uptake increased markedly with age in all three groups of rats but was independent of corticosterone status.

creased ASBT activity and mRNA expression. This possibility, however, is remote, because only replacement injections of thyroxine restored ASBT activity and mRNA abundance in hypothyroid pups and because ASBT expression was independent of endogenous corticosterone (see below).

Administration of exogenous thyroxine in already euthyroid 20- or 26-d-old pups did not result in further increases in rates of bile acid uptake or in abundance of ASBT mRNA, suggesting that physiologic and not pharmacologic levels of thyroxine are sufficient to trigger ASBT development. It is not clear to us why thyroxine injections in euthyroid and particularly in hypothyroid pups would result in serum thyroxine levels more than two times that in euthyroid pups; what is clear is that abnormally high levels of thyroxine did not trigger abnormally high levels of ASBT mRNA or activity.

Although serum thyroxine levels are already elevated in 12-d-old pups, ASBT mRNA abundance and activity are still

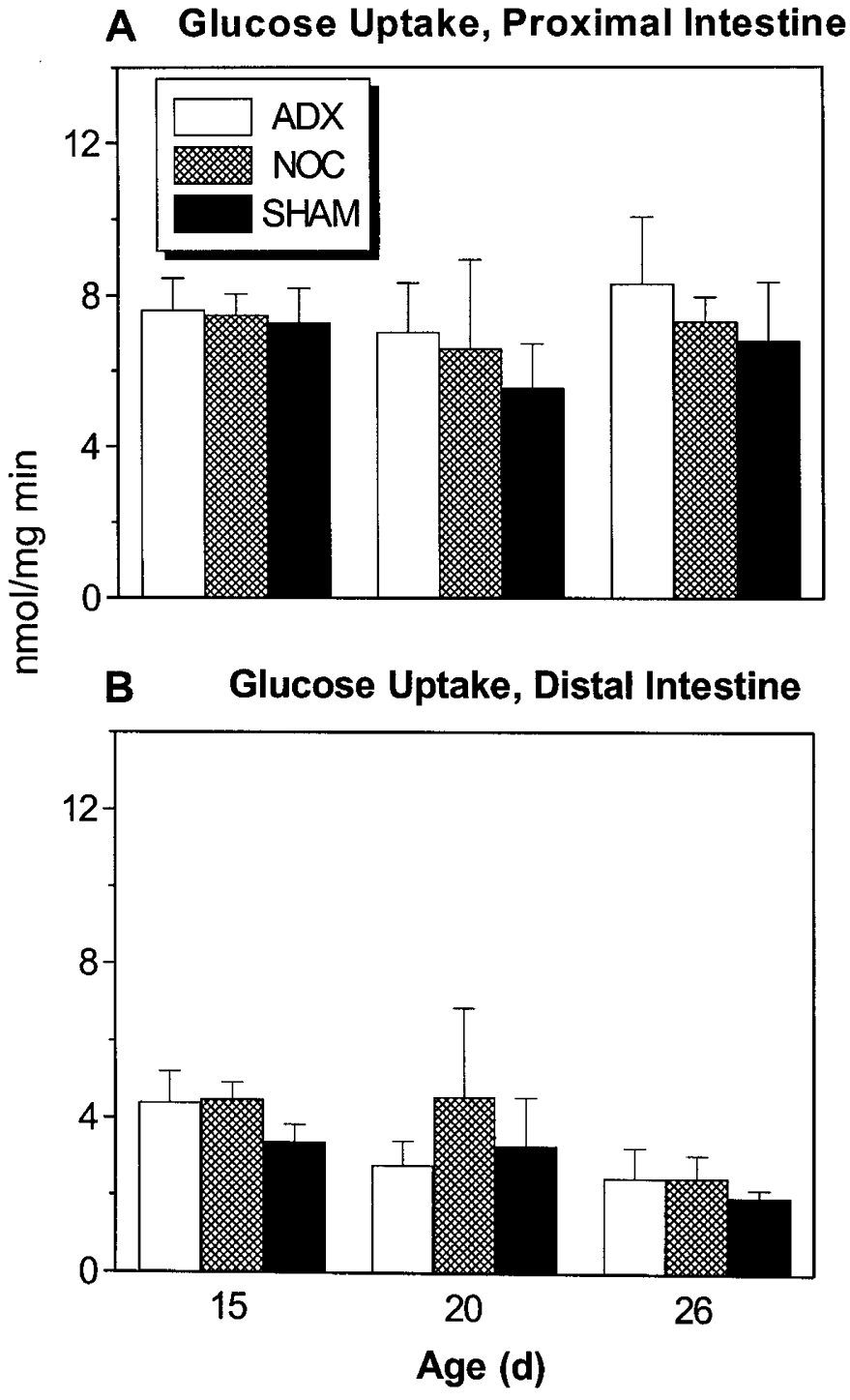

Figure 7. Glucose uptake in the proximal $(A)$ and distal $(B)$ small intestine of ADX, SHAM, or NOC rats. Bars are means $\pm \operatorname{SEM}(n=6-8)$. Uptake in the proximal intestine was higher than that of the distal and was independent of age and treatment. Glucose uptake in the distal region decreased slightly with age in all pups.

low, suggesting that there may be factors other than thyroxine required for ASBT development and that there is definitely a time lag between the thyroxine surge and the increase in ASBT mRNA abundance and activity. This lag may be as long as $8 \mathrm{~d}$ (compare Fig. $1 D$ showing high thyroxine in 12-d-old euthyroid pups with Figs. $2 B$ and $4 B$ showing increased ASBT expression and activity in 20- but not 12-d-old euthyroid pups). The lag must be over $3 \mathrm{~d}$ because 15-d-old euthyroid pups still have low taurocholate uptake rates and ASBT mRNA abundance (see NOC pups in Figs. $6 B$ and 8).

Thyroxine may regulate taurocholate uptake at the level of mRNA abundance, because thyroxine-related changes in mRNA levels were tightly correlated with thyroxine-related changes in taurocholate uptake rates (this study). Similarly, age may also regulate bile acid uptake at the mRNA level, again because of excellent correlation between age-related changes in ASBT mRNA levels with age-related changes in tauro- 
A

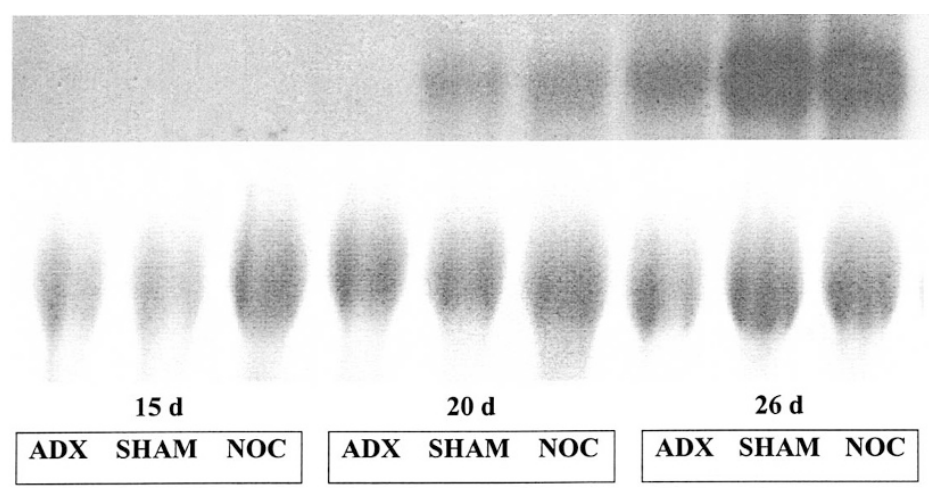

ASBT

$18 \mathrm{~S}$

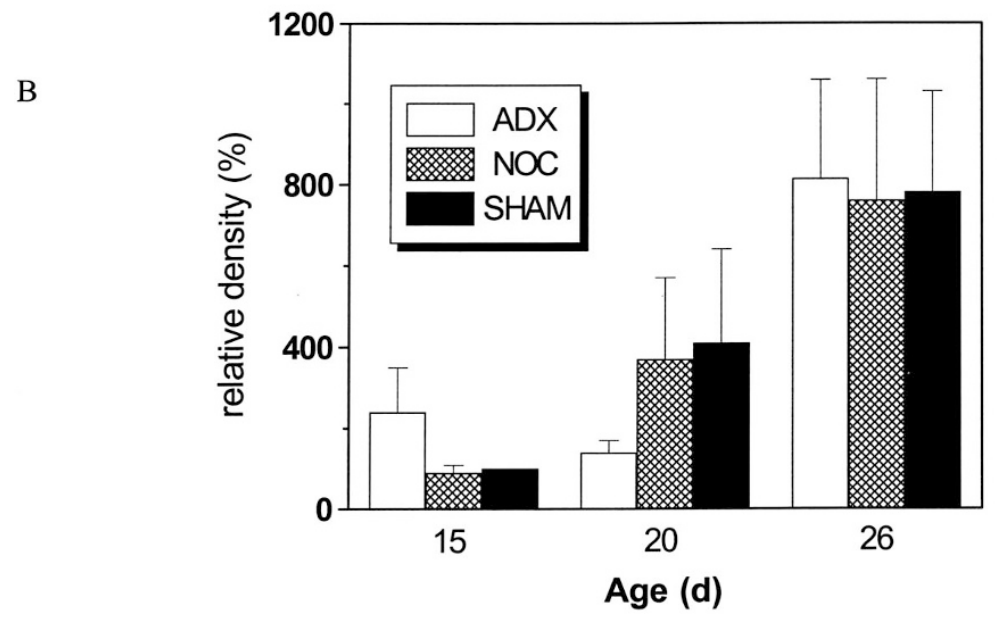

Figure 8. (A) A representative Northern blot analysis of ASBT and 18S rRNA rats. (B) Mean ASBT mRNA abundance in the distal small intestine of ADX, SHAM, or NOC rats. Bars are means \pm SEM $(n=3)$. $18 \mathrm{~S}$ rRNA was used as loading and transfer control. Abundance was initially normalized to $18 \mathrm{~S}$ rRNA, and the normalized ASBT mRNA abundance was expressed relative to that in the distal small intestine of 15-d-old SHAM pups (designated arbitrarily as 100\%). Abundance of ASBT mRNA increased markedly with age but is independent of adrenalectomy.

cholate uptake rates. Changes in mRNA abundance can occur either by alterations in transcription rates or in mRNA stability. These mechanisms should be investigated by direct measurements of ASBT mRNA transcription and degradation rates (32).

Thyroxine also plays an important role in the ontogenetic development of the brush border enzyme lactase. Administration of thyroxine to suckling rat pups resulted in a precocious decline of jejunal lactase activity (33). Thyroxine regulates lactase ontogeny by posttranslational mechanisms that include altered processing and increased degradation of the lactase enzyme (34). In contrast, previous experiments in our laboratory have shown that thyroxine was not essential for the precocious induction of intestinal fructose transport and GLUT5 mRNA expression by high-fructose diets (16).

Hypothyroidism has been shown to decrease both DNA and protein content of the intestinal mucosa (35). This could be the reason for lower intestinal wet weights in our hypothyroid pups. Because feeding rates of milk and chow could not be measured in suckling and weaning stages, we could not determine whether the effect of hypothyroidism on intestinal weight and ultimately on body weight was due to the absence of thyroxine or to reductions in feeding rates and therefore to malnutrition. However, increases in intestinal weight of chick- ens was directly proportional to the level of dietary supplementation of thyroxine (36), suggesting that the effect of thyroxine on intestinal weight is direct.

Normal ASBT development does not require endogenous corticosterone. We found that even in the absence of the corticosterone surge, both abundance of ASBT mRNA and rates of taurocholate uptake in the distal small intestine increased at an appropriate time in rat development. Hence, the signal regulating the developmentally timed appearance of ASBT may not be linked to changes in endogenous corticosterone concentrations. This corticosterone-independent surge in ASBT expression cannot be due to our failure to detect the endogenous corticosterone surge, because serum corticosterone levels were found to increase markedly in SHAM and NOC pups. It cannot be due to damage or abnormal development of distal intestinal tissue in 15-d-old ADX pups because their taurocholate uptake rates and ASBT mRNA abundance were normal and similar to those in 12-d-old pups in the thyroxine study and in 15-d-old SHAM and NOC pups of this study. The endogenous corticosterone surge also does not play a critical role in the substrate-induced, precocious induction of the intestinal fructose transporter GLUT5, a nutrient transporter that, like ASBT, also appears late in development (30). 
The trace levels of corticosterone in the ADX pups may be due to steroid production from the gonads. Trace corticosterone levels are clearly insufficient to induce ASBT expression (Fig. 8), just as trace corticosterone levels in ADX rats do not modulate the development of intestinal sucrase-isomaltase (12, 37). Exogenous corticosterone given to 10- to 13-d-old pups also had no effect on taurocholate uptake in 14- to 16-d-old pups (12).

Pharmacologic doses of exogenous glucocorticoids can increase bile acid transport in adult rats (38), whereas pharmacologic doses of methylprednisolone can precociously induce the appearance of bile acid transport in 14-d-old rat pups (10). Dexamethasone administered during the second postnatal week also induced ASBT and ileal bile acid binding protein expression (11). These findings suggest that administration of pharmacologic or even physiologic doses of exogenous corticosterone or its analogs, perhaps by altering endogenous thyroxine levels, can modify the developmental timetable of ASBT appearance that otherwise is not affected by marked changes in endogenous corticosterone levels.

The ADX pups did not grow well, a finding consistent with many previous studies, mainly because adrenal steroids are necessary for normal GH secretagogue-receptor expression (39). Because endogenous corticosterone is required for intestinal growth (40), adrenalectomy eventually leads to loss of jejunal protein in neonatal rats (41). However, we found in this and in a previous study (18) that intestinal wet weight does not decrease until after $1 \mathrm{wk}$ after adrenalectomy. Other studies have also suggested that adrenalectomy has no short-term effect on intestinal weight of suckling rats (42).

ASBT $m R N A$ abundance and activity in the distal intestine increase with age. The expression of ASBT $\mathrm{mRNA}$ and the rate of taurocholate uptake are greatest in the distal region, as shown previously (27). Developmental increases of bile acid uptake and mRNA abundance in the distal small intestine were noted in the pups at 20 and $26 \mathrm{~d}$ of age compared with those at $12 \mathrm{~d}$ of age in both thyroxine and corticosterone studies. These findings parallel previous work. Taurocholate transport in rat ileal brush border membrane vesicles is incompletely developed at 2 wk of age but is fully developed by the time of weaning at $3 \mathrm{wk}$ of age (10). ASBT expression has a prenatal onset of expression followed by repression and then a marked reinduction at weaning (4).

Contribution of diffusive component to total taurocholate uptake. The low uptake rates in the ASBT mRNA-deficient distal intestine of 20- and 26-d-old HT- pups represent passive uptake. These rates are similar to rates observed in the distal intestine of ASBT-deficient 12- (thyroxine study) and 15-d-old (corticosterone study) normal pups and to rates in the proximal intestine of all rats in both studies. Uptake in the proximal intestine, which has little ASBT mRNA (27), is passive (1).

There may be a significant contribution of a diffusive component in taurocholate uptake by the distal small intestine. At $6 \mathrm{mM}$ taurocholate, we estimate the diffusive component to contribute $5-10 \%$ of total taurocholate uptake in the rat distal small intestine. This is not surprising because taurocholate is an amphipathic, relatively hydrophobic compound that can potentially diffuse through the brush border membrane, a process that may be similar to the Na-independent uptake of taurocholate described previously (27). Na-independent uptake represents $\sim 10 \%$ of taurocholate uptake in the distal ileum and almost $100 \%$ of uptake in the jejunum $>12 \mathrm{~cm}$ away from the ileocecal valve. The apparent $\mathrm{K}_{\mathrm{m}}$ of taurocholate uptake in everted sleeves is $0.5 \mathrm{mM}$, a concentration similar to those estimated using brush border membrane vesicles (and therefore no unstirred layer that increases the apparent $\mathrm{K}_{\mathrm{m}}$ ) from the intestine of rats $\left[\mathrm{K}_{\mathrm{m}}=0.13 \mathrm{mM}(43)\right]$ and cats $\left[\mathrm{K}_{\mathrm{m}}=0.12\right.$ $\mathrm{mM}(44)]$.

Future studies. It not yet known whether there is a thyroid hormone response element in the ASBT promoter through which the thyroid hormone and its receptor can directly interact. However, the ASBT promoter seems to have activator multiprotein complex-1 (AP-1) (45) and hepatocyte nuclear factor $1 \alpha$ (46) recognition sites that participate in the regulation of the rat and human ASBT gene. It will be interesting to determine whether thyroxine regulates ASBT1 through transcription factors such as activator multiprotein complex-1 (AP-1) and hepatocyte nuclear factor and/or with other receptors such as the retinoid X receptor, which form strong heterodimers with the thyroid hormone receptor, and such as the farnesoid $\mathrm{X}$ receptor, which regulates the ontogenetic expression of rat ileal bile acid binding proteins (47). The availability of genetically modified mouse models deficient in these factors and receptors should facilitate studies on ASBT regulation at the molecular level.

Acknowledgments. We are grateful to Ellery Canlas and Lisa $\mathrm{Wu}$ for excellent technical help and to Drs. Ben Shneider, Lan Jiang, and Mary Dudley for valuable discussion. We also thank Dr. Shneider for the ASBT cDNA.

\section{REFERENCES}

1. Dietschy JM 1974 Bile acids: their absorption from the gastrointestinal tract and role during fat absorption. Verh Dtsch Ges Inn Med 80:399-407

2. Love MW, Dawson PA 1998 New insights into bile acid transport. Curr Opin Lipido 9:225-229

3. de Belle RC, Vaupshas V, Vitullo BB, Haber LR, Shaffer E, Mackie GG, Owen H, Little JM, Lester R 1979 Intestinal absorption of bile salts: immature development in the neonate. J Pediatr 94:472-476

4. Shneider BL, Setchell KD, Crossman MW 1997 Fetal and neonatal expression of the apical sodium-dependent bile acid transporter in the rat ileum and kidney. Pediatr Res 42:189-194

5. Buddington RK, Diamond JM 1989 Ontogenetic development of intestinal nutrient transporters. Annu Rev Physiol 51:601-619

6. Cui X, Jiang L, Ferraris RP 2003 Regulation of rat intestinal GLUT2 mRNA abundance by luminal and systemic factors. Biochim Biophys Acta 1612:178-185

7. Henning SJ 1987 Functional development of gastrointestinal tract. In: Johnson LR (ed) Physiology of the Gastrointestinal Tract, 2nd Ed., pp 285-300. Raven Press, New York

8. Henning SJ 1981 Postnatal development: coordination of feeding, digestion, and metabolism. Am J Physiol 241:G199-G214

9. Little JM, Lester R 1980 Ontogenesis of intestinal bile salt absorption in the neonatal rat. Am J Physiol 239:G319-G323

10. Barnard JA, Ghishan FK 1986 Methylprednisolone accelerates the ontogeny of sodium-taurocholate cotransport in rat ileal brush border membranes. J Lab Clin Med 108:549-555

11. Hwang ST, Henning SJ 2001 Ontogenic regulation of components of ileal bile acid absorption. Exp Biol Med (Maywood) 226:674-680

12. Heubi JE, Gunn TD 1985 The role of glucocorticoids in the postnatal development of ileal active bile salt transport. Pediatr Res 19:1147-1151

13. Heubi JE 1986 Role of thyroxine on postnatal development of ileal active bile salt transport. Am J Physiol 251:G237-G242

14. Shneider BL, Michaud GA, West AB, Suchy FJ 1993 The effects of bile acid feeding on the development of ileal bile acid transport. Pediatr Res 33:221-224

15. Stravitz RT, Sanyal AJ, Pandak WM, Vlahcevic ZR, Beets JW, Dawson PA 1997 Induction of sodium-dependent bile acid transporter messenger RNA, protein, and activity in rat ileum by cholic acid. Gastroenterology 113:1599-1608 
16. Monteiro IM, Jiang L, Ferraris RP 1999 Dietary modulation of intestinal fructose transport and GLUT5 mRNA expression in hypothyroid rat pups. J Pediatr Gastroenterol Nutr 29:563-570

17. Blake HH, Henning SJ 1985 Effect of propylthiouracil dose on serum thyroxine, growth, and weaning in young rats. Am J Physiol 248:R524-R530

18. Monteiro IM, Ferraris RP 1997 Precocious enhancement of intestinal fructose uptake by diet in adrenalectomized rat pups. Pediatr Res 41:353-358

19. Martin GR, Henning SJ 1984 Enzymic development of the small intestine: are glucocorticoids necessary? Am J Physiol 246:G695-G699

20. Karasov WH, Diamond JM 1983 Adaptive regulation of sugar and amino acid transport by vertebrate intestine. Am J Physiol 245:G443-G462

21. Boehm G, Braun W, Moro G, Minoli I 1997 Bile acid concentrations in serum and duodenal aspirates of healthy preterm infants: effects of gestational and postnatal age. Biol Neonate 71:207-214

22. Kanda T, Niot I, Foucaud L, Fujii H, Bernard A, Ono T, Besnard P 1996 Effect of bile on the intestinal bile-acid binding protein (I-BABP) expression. In vitro and in vivo studies. FEBS Lett 384:131-134

23. Lewis MC, Root C 1990 In vivo transport kinetics and distribution of taurocholate by rat ileum and jejunum. Am J Physiol 259:G233-G238

24. Chomczynski P, Sacchi N 1987 Single-step method of RNA isolation by acid guanidinium thiocyanate-phenol-chloroform extraction. Anal Biochem 162:156-159

25. Karasov WH, Diamond JM 1983 A simple method for measuring intestinal solute uptake in vitro. J Comp Physiol 152:105-116

26. Takikawa H, Yokote M, Sano N, Kuyama Y, Yamanaka M 1997 Absorption of unconjugated bile acids and tauroursodeoxycholate in the rat intestine. J Gastroenterol Hepatol 12:815-821

27. Stelzner M, Hoagland V, Somasundaram S 2000 Distribution of bile acid absorption and bile acid transporter gene message in the hamster ileum. Pflugers Arch 440:157-162

28. Shneider BL 2001 Intestinal bile acid transport: biology, physiology, and pathophysiology. J Pediatr Gastroenterol Nutr 32:407-417

29. Jiang L, Ferraris RP 2001 Developmental reprogramming of rat GLUT-5 requires de novo mRNA and protein synthesis. Am J Physiol 280:G113-G120

30. Jiang L, David ES, Espina N, Ferraris RP 2001 GLUT-5 expression in neonatal rats: crypt-villus location and age- dependent regulation. Am J Physiol 281:G666-G674

31. Walker P, Dubois JD, Dussault JH 1980 Free thyroid hormone concentrations during postnatal development in the rat. Pediatr Res 14:247-249

32. Christie DM, Dawson PA, Thevananther S, Shneider BL 1996 Comparative analysis of the ontogeny of a sodium-dependent bile acid transporter in rat kidney and ileum. Am J Physiol 271:G377-G385
33. Paul T, Flatz G 1983 Temporary depression of lactase activity by thyroxine in suckling rats. Enzyme 30:54-58

34. Liu T, Reisenauer AM, Castillo RO 1992 Ontogeny of intestinal lactase: posttranslational regulation by thyroxine. Am J Physiol 263:G538-G543

35. Ardawi MS, Jalalah SM 1991 Effects of hypothyroidism on glucose and glutamine metabolism by the gut of the rat. Clin Sci (Lond) 81:347-355

36. Chang SC, Lin MJ, Croom J, Fan YK 2003 Administration of triiodothyronine and dopamine to broiler chicks increases growth, feed conversion and visceral organ mass. Poult Sci 82:285-293

37. Nanthakumar NN, Henning SJ 1993 Ontogeny of sucrase-isomaltase gene expression in rat intestine: responsiveness to glucocorticoids. Am J Physiol 264:G306-G311

38. Nowicki MJ, Shneider BL, Paul JM, Heubi JE 1997 Glucocorticoids upregulate taurocholate transport by ileal brush-border membrane. Am J Physiol 273:G197G203

39. Thomas GB, Bennett PA, Carmignac DF, Robinson IC 2000 Glucocorticoid regulation of growth hormone $(\mathrm{GH})$ secretagogue-induced growth responses and $\mathrm{GH}$ secretagogue receptor expression in the rat. Growth Horm IGF Res 10:45-52

40. Yeh KY, Yeh M, Holt PR 1987 Hormonal regulation of adaptive intestinal growth in artificially reared rat pups. Am J Physiol 253:G802-G808

41. Boyle JT, Koldovsky O 1980 Critical role of adrenal glands in precocious increase in jejunal sucrase activity following premature weaning in rats: negligible effect of food intake. J Nutr 110:169-177

42. Kaouass M, Deloyer P, Dandrifosse G 1997 Involvement of bombesin in spermine induced corticosterone secretion and intestinal maturation in suckling rats. J Endocrinol 153:429-436

43. Moyer MS, Heubi JE, Goodrich AL, Balistreri WF, Suchy FJ 1986 Ontogeny of bile acid transport in brush border membrane vesicles from rat ileum. Gastroenterology 90:1188-1196

44. Wolffram S, Grenacher B, Scharrer E 1993 Intestinal transport of taurocholate in the cat. Zentralbl Veterinarmed A 40:178-184

45. Chen F, Ma L, Al-Ansari N, Shneider B 2001 The role of AP-1 in the transcriptiona regulation of the rat apical sodium-dependent bile acid transporter. J Biol Chem 276:38703-38714

46. Jung D, Fried M, Kullak-Ublick GA 2002 Human apical sodium-dependent bile salt transporter gene (SLC10A2) is regulated by the peroxisome proliferator-activated receptor alpha. J Biol Chem 277:30559-30566

47. Hwang ST, Urizar NL, Moore DD, Henning SJ 2002 Bile acids regulate the ontogenetic expression of ileal bile acid binding protein in the rat via the farnesoid $\mathrm{X}$ receptor. Gastroenterology 122:1483-1492 